\title{
Historical Mosque Al-Sadiq
}

\author{
Nusrat Bibi* \\ Department of Textile Design, University College of Art \& Design, Faculty of Arts, The Islamia University of Bahawalpur, Pakistan \\ DOI: 10.29322/IJSRP.11.10.2021.p11833 \\ http://dx.doi.org/10.29322/IJSRP.11.10.2021.p11833
}

\begin{abstract}
Al-Sadiq Mosque is a mosque positioned in Bahawalpur (main city Shahi Bazar) Punjab, Pakistan. Its groundwork stone used to be arranged by way of Great Sufi of Chishtia clan and the Mystical Master of Nawab of Bahawalpur Noor Muhammad Maharvi more than two hundred years ago. The renewal used to be done through the order of Sir Sadiq Muhammad Khan Abbasi V in 1935 after returning from hajj. 50 to 60 thousand humans can pray in the mosque at a time. Masjid al-Sadiq is a unique mosque in terms of beauty and structure Nawab of Bahawalpur's love of religion, attachment and friendship with knowledge. The stones have been sourced and high quality wood and stones have been imported.
\end{abstract}

\section{INTRODUCTION}

$\mathrm{M}$ asjid al-Sadiq (located at Bahawalpur Shahi Bazar) and Bahawalpur's Shahi Mosque (located at near Derawar Fort in Cholistan) is one of the two stately mosques with a façade dressed totally with white marble imported from Central Asia. It is additionally one of the two biggest mosques built with the aid of the Ameers of Bahawalpur, and possibly the ultimate monument of notice to have been commissioned earlier than the nation acceded to

Index Terms- Mosque, Stone, History, Religious

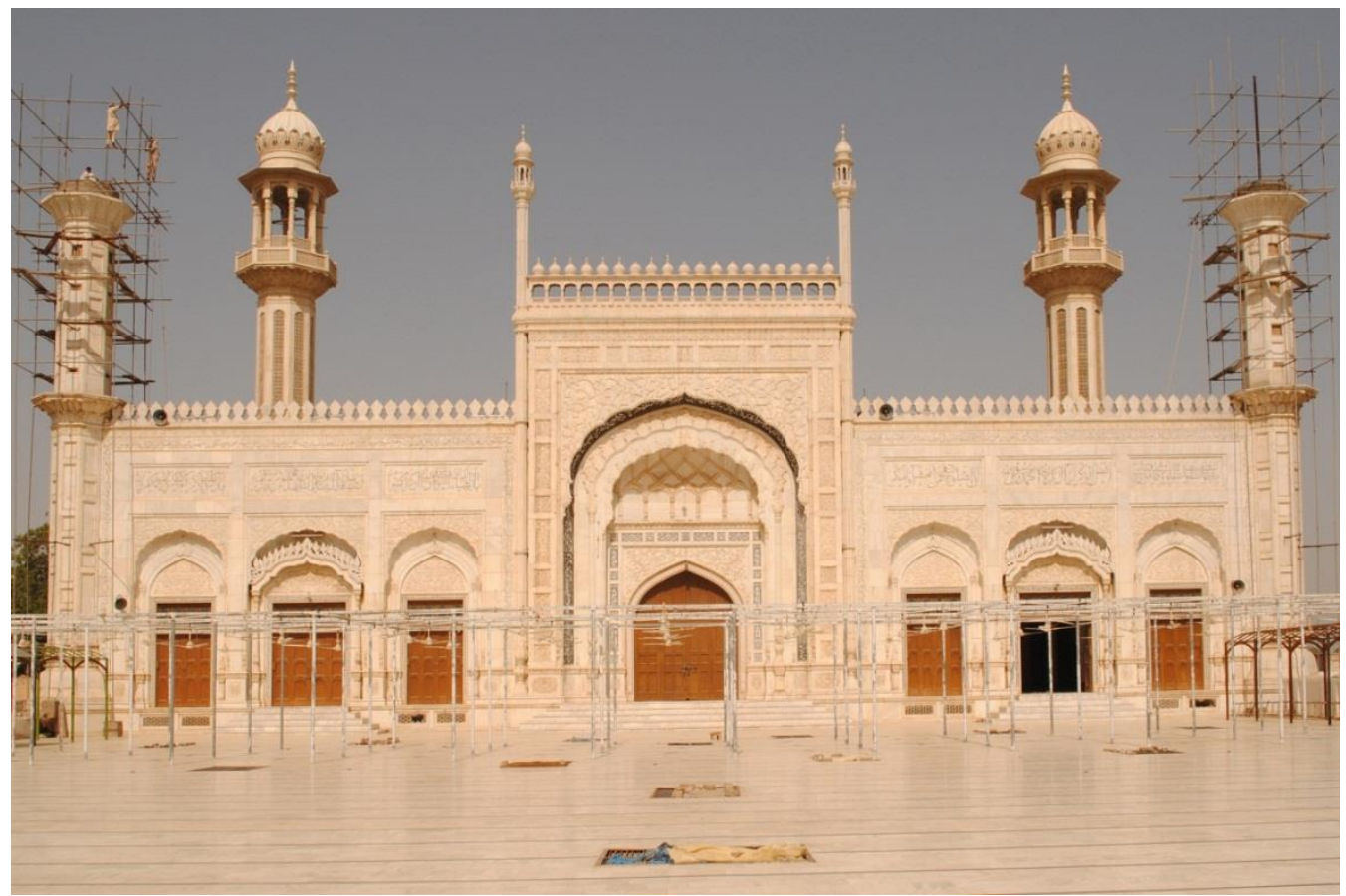

Pakistan. Commissioned by using Ameer Sadiq Muhammad Khan $\mathrm{V}$ and built at the nation expense, the mosque was in no way virtually finished, and stays incomplete. Bahawalpur's Jamia Mosque; it is positioned centrally in Chowk Bazaar, built over a basement containing stores and warehouses. The most commonly used direction to the mosque leads via Shahi Bazaar and Farid Gate, but the mosque is additionally approachable from Ahmadpuri Gate, which is closer. Before the building of the
Masjid, the location was engaged by a state court structure and a palace preserved by a state minister. The front portico of the mosque contains seven arched openings with doors of teak. The two arches at both quit of the façade are smallest, the remaining arches are gradually larger, with the central arch being the largest. The building's façade is of molded base putty of white marble, and the dasa is embellished with floral designs. The panel inner the chamber is dressed with semiprecious stone (onyx). 


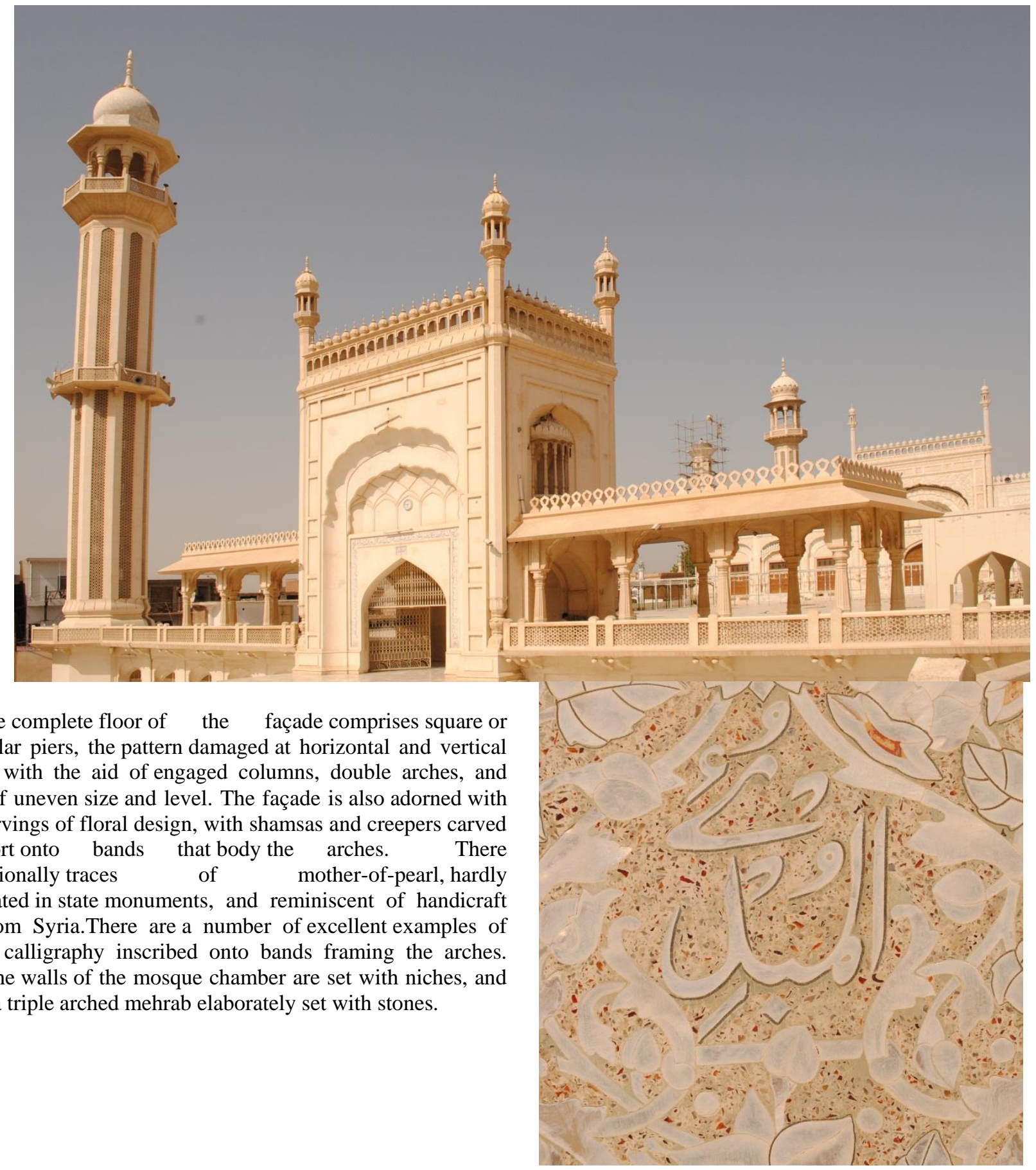




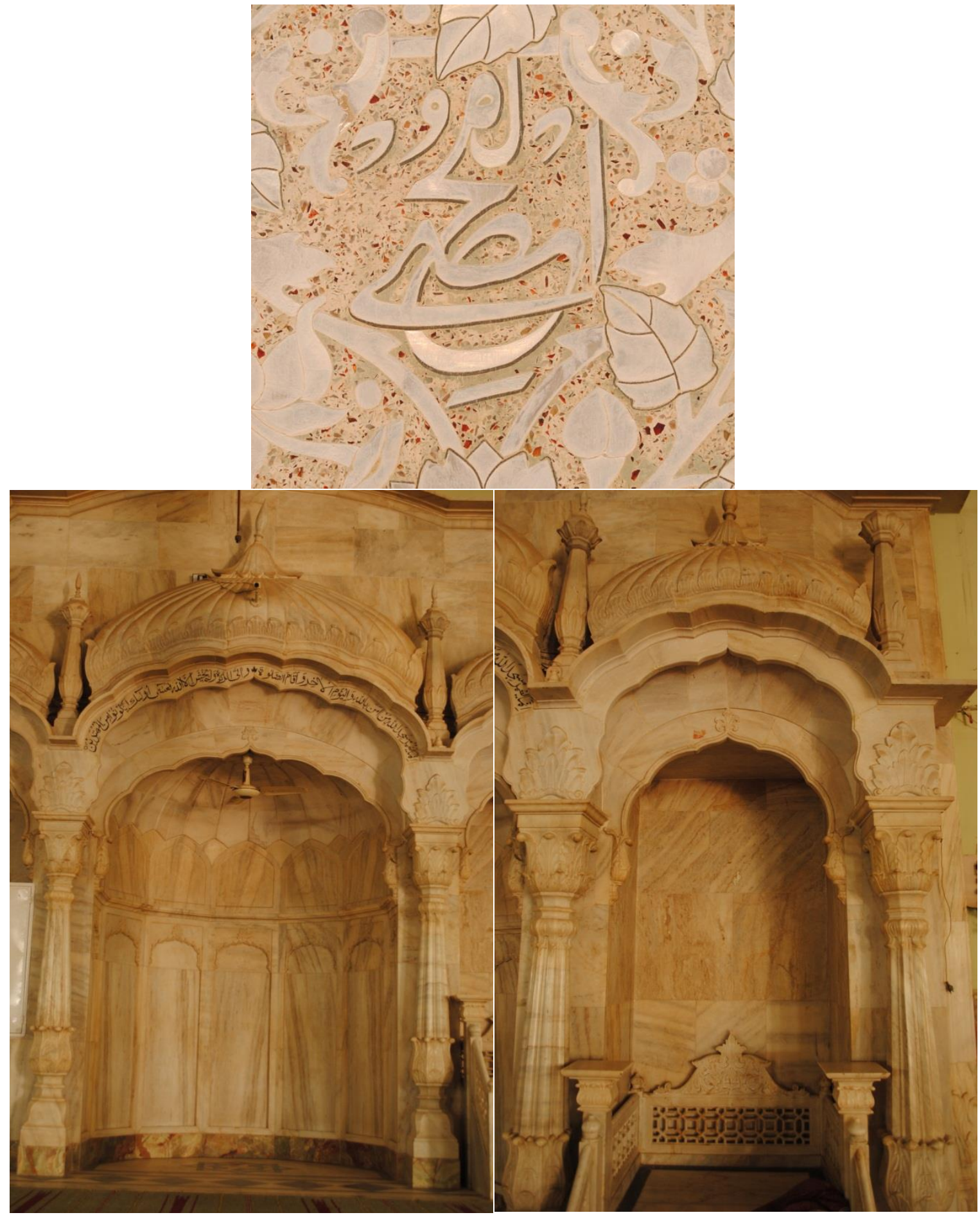

The mimbar is constructed of the same material as the

chamber. The floor has a black-chip finish, laid out in north-south strips and bordered via a slender black strip. mebrab, and set in a small area of interest at the north stop of the 


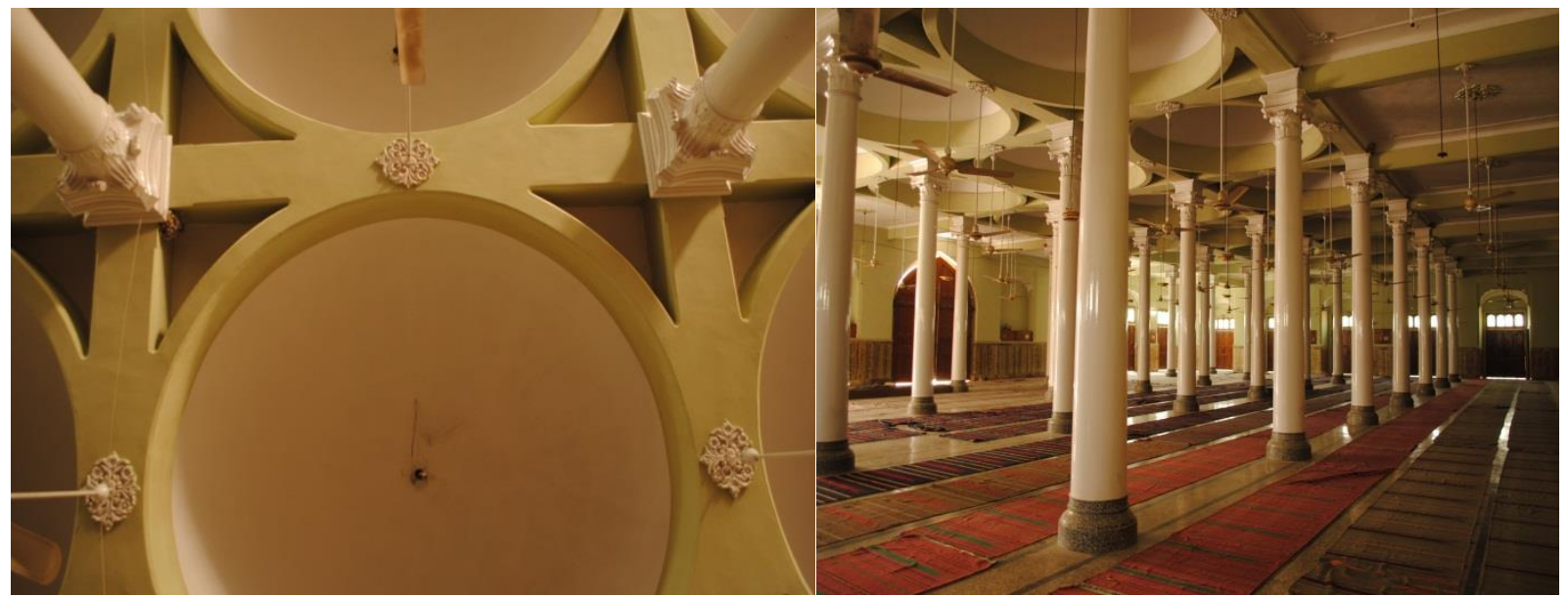

The roof of the chamber is supported by means of thirty-two

hemispheric inverted cups, seven in every row, are seen on the ceiling. The roof of the mosque has 4 minarets, the two at columns finished in white marble. The curved space is divided into horizontal north-south strips by inverted beams. Twenty-one the returned are lower than the two in front.

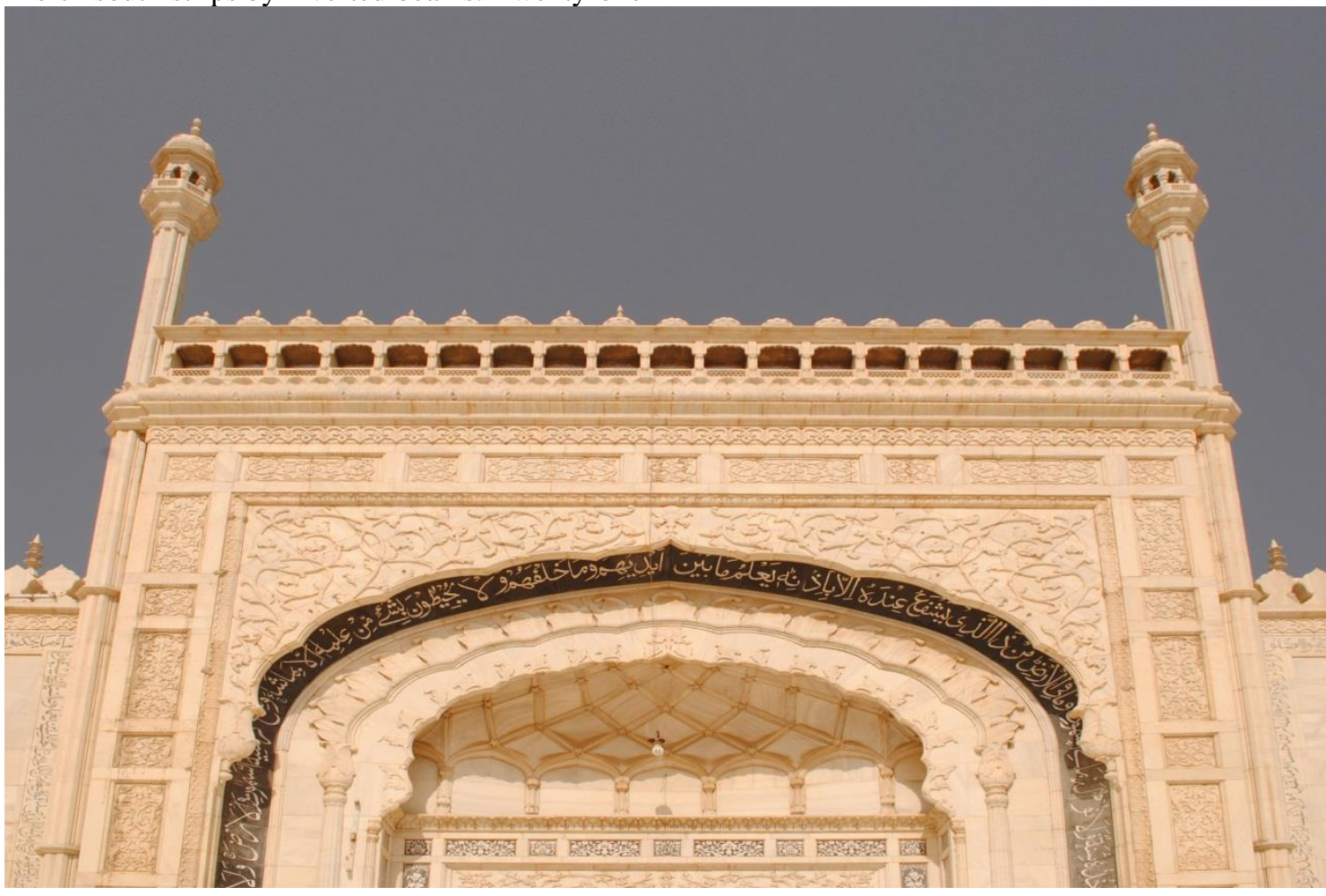

be used both for ablution and construction purposes. The

Underground pipes carried water from the Sutlej River, then $4 \mathrm{~km}$ away, to the construction site, and this water used to water used to be saved in a close by well. Staircases on the south, north, and east facets lead into this compound. 


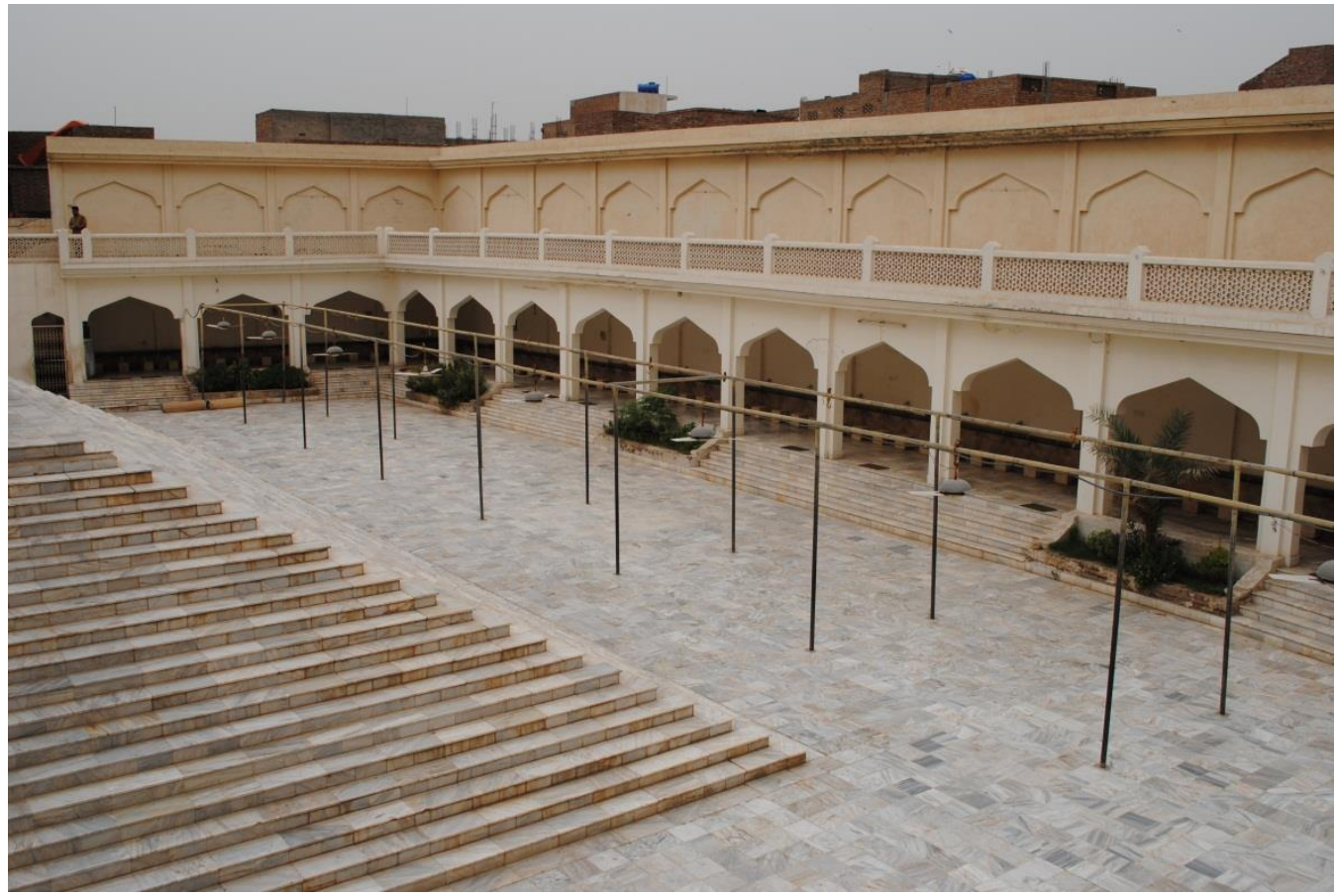

The most days built with economic help from Shaikh Rashed ruler of Dubai, is a double-storey constructing with arched openings and 4 turrets, similar to those on peak of the most important compartment. The structure of this compound has a lime putty finish. The facade of the basement on the west and partly on the north is dressed with red sandstone imported from India. Here is also a façade of pink sandstone at the stage of the chamber floor; the facade is supported by brackets of the equivalent material. Jamia Al-Sadiq Mosque is a great architectural masterpiece.

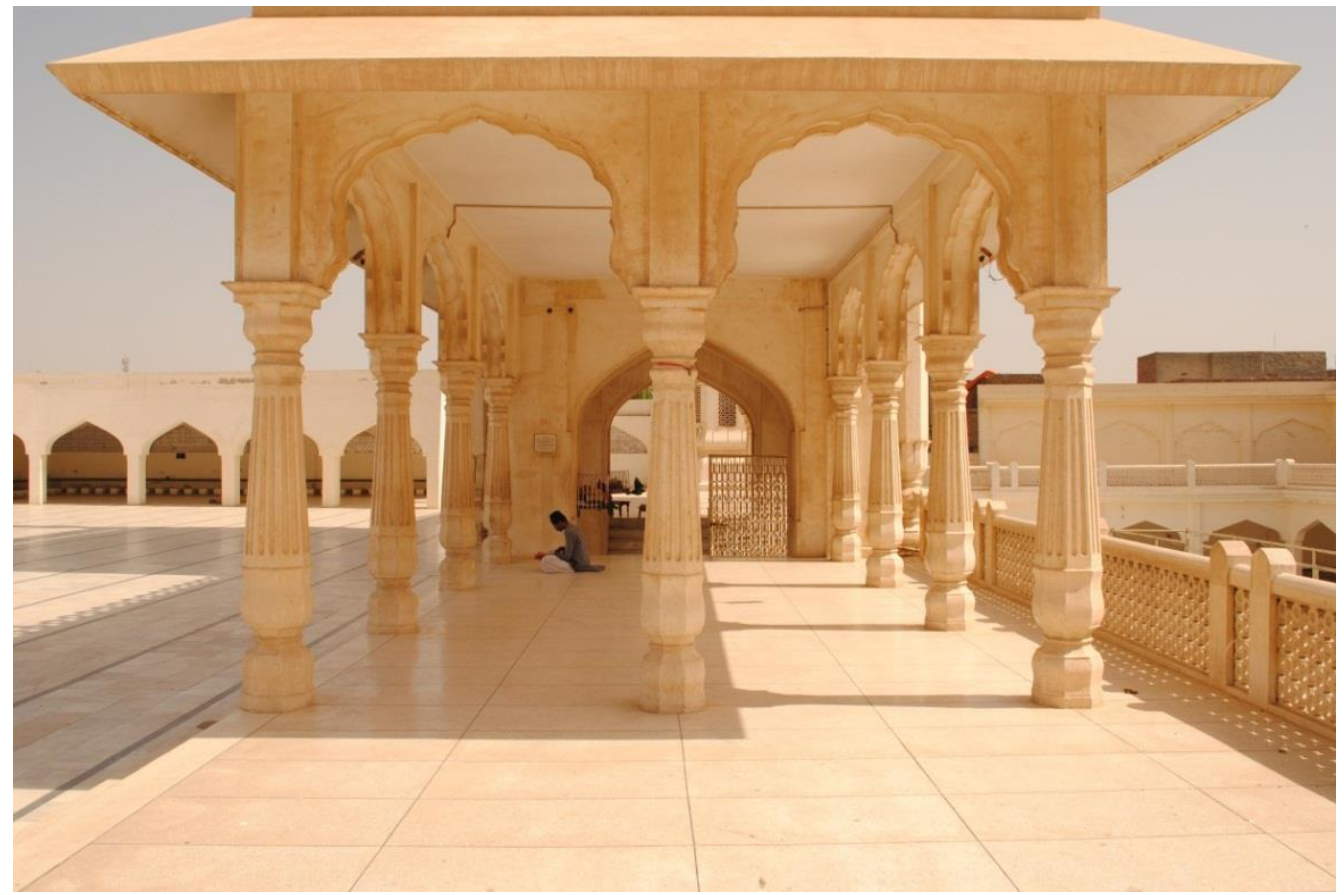

This publication is licensed under Creative Commons Attribution CC BY. 

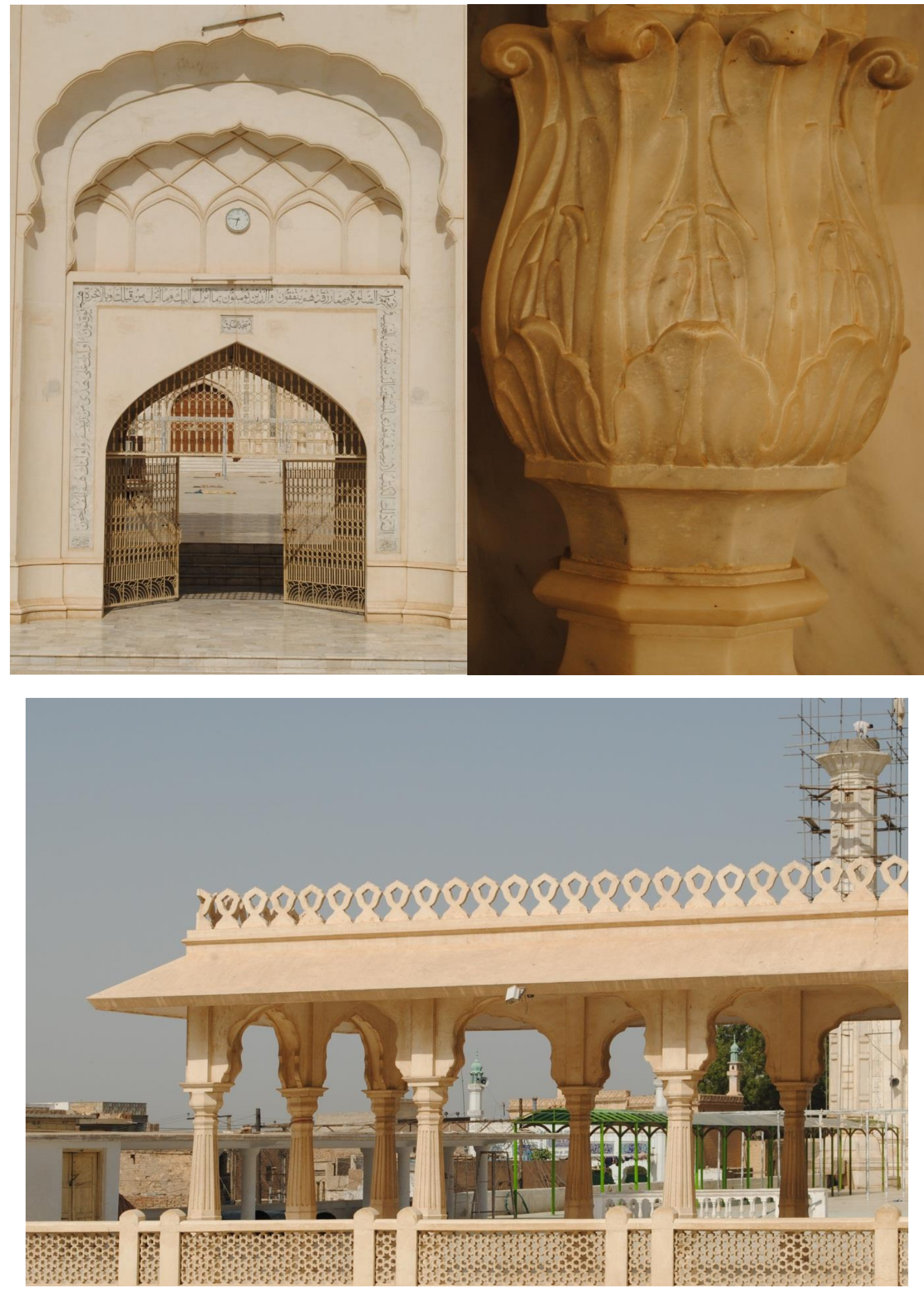

\section{REFERENCES}

[1] Al-Sadiq Mosque Bahawalpur, Available at online Wikipedia

This publication is licensed under Creative Commons Attribution CC BY. 
[2] Ahsan Ansari (May 18, 2019). Explore Bahawalpur's 150-year-old mosque. SAMAA

[3] Interactive Desk ( 21 Mar, 2016). 9 historical Pakistani mosques that will transport you to another time. DAWN

[4] Al-Sadiq Mosque, Bahawalpur. Auqaf \& Religious Affairs Department, Government of the Punjab

[5] Stunning Pakistan (Nov, 2020). Al Sadiq Jamia Mosque Bahawalpur | Streets of old Bahawalpur. Available at YouTube

\section{AUTHORS}

First Author - Nusrat Bibi (Assistant Professor), Department of Textile Design, University College of Art \& Design, Faculty of Arts, The Islamia University of Bahawalpur, Pakistan, Mail ID: nusratbibi1987@gmail.com, Cell\#03008667684 